деятельности РФ за счет активного внедрения цифровых технологий на рынке и обеспечения защиты национальных экономических интересов в рамках ГЦС.

$$
* * *
$$

1. Концепция долгосрочного социально-экономического развития Российской Федерации на период до 2020 года от 17.11.2008 № 1662-р: утверждена распоряжением Правительства Российской Федерации от 17.11.2008 г. № 1662-p [ред. от 28.09.2018 г.]. [Электронный ресурс]. Режим доступа: http://www.consultant.ru/document/cons_doc_LAW_82134/28c7f9e359e8af09d7244d8033c66928fa27e527/ (дата обращения: 07.09.2021).

2. Государственная программа Российской Федерации «Развитие внешнеэкономической деятельности»: утверждена постановлением Правительства РФ от 15.04.2014 г. № 330: [ред. от 28.03.2019]. [Электронный pecypc]. Режим доступа: http://gov.garant.ru/SESSION/PILOT/main.htm/ (дата обращения: 07.09.2021).

3. Министерство экономического развития Российской Федерации. [Электронный ресурс]. Режим доступа: http://economy.gov.ru/ (дата обращения: 07.09.2021).

4. Федеральный закон от 08.12.2003 N 164-Ф3 (ред. от 22.12.2020) «Об основах государственного регулирования внешнеторговой деятельности»

5. Федеральная служба государственной статистики URL: https://rosstat.gov.ru/ (дата обращения: 07.09.2021).

6. Н. Д. Кондратьев кризисы и прогнозы в свете теории длинных волн. Взгляд из современности. Под редакцией Л. Е. Гринина, А. В. Коротаева, В. М. Бондаренко Москва: Учитель, 2017.

7. Мировое хозяйство. Понятие и этапы развития мирового хозяйства // EREPORT.RU Мировая экономика URL: http://www.ereport.ru/articles/mirecon/mirhoz.htm (дата обращения: 07.09.2021).

8. Россия. Особые экономические зоны. [Электронный ресурс] - Режим доступа: http://www.russez.ru/

9. Государственная программа Российской Федерации «Развитие внешнеэкономической деятельности» // Министерство экономического развития Российской Федерации URL: https://www.economy.gov.ru/material/departments/d12/gp_rf_razvitie_vneshneekonomicheskoy_deyatelnosti/ (дата обращения: 26.09.2021).

10. Аналитика АКИТ // Ассоциация компаний интернет торговли URL: https://akit.ru/category/analytics/ (дата обращения: 26.09.2021).

11. Личный кабинет участника ВЭД // Федеральная Таможенная Служба URL: https://edata.customs.ru/FtsPersonalCabinetWeb2017/ (дата обращения: 26.09.2021).

12. Экосистема Сбербанка (SberX) // TADVISER URL: https:/www.tadviser.ru/index.php/ (дата обращения: 11.09.2021).

13. Батов, Г.Х. Пути и факторы, обеспечивающие переход экономики субъектов макрорегиона на новый технологический уклад / Г.Х. Батов // МИР (Модернизация. Инновации. Развитие). - 2018. - С. 200-212.

14. Россия в 2021 году // OC «Льготы Всем». URL: https://goty-vsem.ru/mat-kapital/izmeneniya/rossiya-v-2021godu-vosstanovitsya-li-ekonomika-polnyj-analiz.html

15. https://economy.gov.ru/material/directions/tehnologicheskoe_razvitie/

16. Наука и инновации // Национальный статистический комитет Республики Беларусь. URL: https://belstat.gov.by/ofitsialnaya-statistika/realny-sectorekonomiki/nauka-i-innovatsii

\title{
Кущева А.E. \\ Рынок IPO в год пандемии
}

Финансовый университет при Правительстве РФ (Россия, Москва)

doi: 10.18411/trnio-12-2021-39

\section{Аннотация}

Влияние пандемии продолжает играть значительную роль во всех сферах привычной жизни, в том числе и рынке IPO. В статье проведен обзор рынка IPO в 2020 году, в частности анализ распределения привлеченных средств по компаниям и секторам. Отдельное внимание уделено факторам успеха IPO в прошедшем году.

Ключевые слова: экономика, IPO, пандемия, COVID-19, рынок ценных бумаг.

\section{Abstract}

The impact of pandemic continues to play a significant role in all spheres of everyday life, including the IPO market. The article provides an overview of the IPO market in 2020, in particular, 
an analysis of the distribution of funds raised by companies and sectors. Special attention is paid to the factors of IPO success in the past year.

Keywords: economy, IPO, pandemic, COVID-19, security market.

Компания прибегает к первичному публичному предложению (Initial Public Offering, далее - IPO), когда испытывает острую необходимость в привлечении денежных средств для поддержания и активизации своей деятельности. Помимо дополнительных денежных средств, IPO позволяет оценить компанию через рыночную стоимость. Что приносит свои плоды: компании проще получить кредит, успешно провести сделку слияния и др.

2019 год внес свои изменения в привычный уклад жизни человека, в том числе без трудностей не обошлось и в сфере экономики. Мировое сообщество столкнулось с неожиданной и глобальной проблемой - пандемией коронавирусной инфекции. Самоизоляция, сложная эпидемиологическая обстановка нанесли сильный удар по бизнесу многих компаний, даже крупных.

Пандемия коронавируса, по мнению исследователей, вытеснила все другие экономические и торговые проблемы и оказала существенное влияние на рынок ценных бумаг в целом и на активность IPO в частности. Фондовый рынок отметился снижением стоимости акций компаний, связанных с теми отраслями и сферами деятельности, которые оказались под ударом ограничительных мер - нефть, газ, туризм, сервис; многие инвесторы стали продавать акции, ожидая падения цен. Закономерным стало и падение связанных с ними индексов. Такие условия стали причиной неоднозначного отношения бизнеса к целесообразности проведения IPO до разрешения эпидемиологической ситуации, но многие компании все равно продолжили подготовку к IPO и сумели найти в подобных обстоятельствах преимущества для привлечения инвестиций.

2020 год стал одним из лучших для фондового рынка. По итогам 2020 года фондовые индексы выросли, а многие компании вышли на биржи при помощи успешных IPO.

Несмотря на COVID-19 и его экономические последствия, IPO провели 1755 эмитентов, увеличившись на 30\% по сравнению с 2019 годом - 1340 эмитентов, суммарно было привлечено 324,14 млрд. долл. США. (в 2019 году - 203,66 млрд. долл. США).

Рынки IPO развивались на основе импульса, который был замечен еще в IV кв. 2019 года - он охватил и I кв. 2020 года, однако на фоне повсеместного ввода ограничений на деятельность бизнес-субъектов активность IPO стала снижаться с марта 2020 года. Эти тенденции стали справедливы для всех мировых регионов.

По объему привлеченных средств первое место занимает американский рынок, несмотря на то, что китайский рынок превзошел по количеству компаний, которые провели IPO (392 компании в США против 518 в Китае). Американские компании за 2020 год привлекли 143,6 млрд. долл. США, что составило 44,3\% всего мирового объема, в то время как китайские компании привлекли 100,3 млрд, долл. США (30,9\% мирового объема). Японские компании стали третьими по количеству размещений (95 компаний), а по размеру сборов - десятыми (3,52 млрд. долл. США) [1].

Как правило, компании откладывают IPO, когда полагают, что рынок слишком слаб, но в 2020 году ряд компаний отложили свои IPO из-за слишком сильного рынка. Так, игровая компания Roblox Inc. и финансово-технологический стартап Affirm Holdings Inc. решили отложить, запланированные на декабрь, IPO после резкого скачка в первый же день котировок акций Airbnb Inc. (рост на $143 \%$ в первый день) и DoorDash Inc. (рост на 86\%). При таком резком росте компании теряют денежные средства, которые могли бы получить, если бы установили более высокую цену размещения, таким образом, выгоду получают инвесторы, которые приобрели акции компаний во время IPO. Другой причиной переноса IPO стали задержки в согласовании заявок в SEC, так как американский регулятор не справлялся с наплывом запросов на листинг [2].

Самое крупное IPO в прошедшем году провела китайская компания Beijing-Shanghai High-Speed Railway - железнодорожная компания, занимающаяся строительством 
магистрали. Компания вышла на Шанхайскую биржу 16 января 2020 года и привлекла 4,4 млрд. долл. США.

Второе место занял Pershing Square Tontine Holdings, собрав 4 млрд. долл. США -американская компания по целевым слияниям и поглощениям.

Таблий 1

5 крупнейших IPO 2020 года [1]

\begin{tabular}{|c|c|c|c|c|c|c|}
\hline & Компания & Страна & Сектор & Биржа & Дата выхода & $\begin{array}{c}\text { Сумма, } \\
\text { млрд. } \\
\text { долл. } \\
\text { США }\end{array}$ \\
\hline 1 & $\begin{array}{c}\text { Beijing-Shanghai } \\
\text { High-Speed } \\
\text { Railway }\end{array}$ & Китай & Транспорт & SSE & 16.01 .20 & 4,405 \\
\hline 2 & $\begin{array}{l}\text { Pershing } S q \\
\text { Tontine }\end{array}$ & США & $\begin{array}{c}\text { Инвестиционный } \\
\text { траст }\end{array}$ & NYSE & 22.07 .20 & 4 \\
\hline 3 & $\begin{array}{l}\text { JD Health } \\
\text { International }\end{array}$ & Китай & Ретейл & $\begin{array}{l}\text { SE Hong } \\
\text { Kong }\end{array}$ & 08.12 .20 & 3,999 \\
\hline 4 & Snowflake & США & $\begin{array}{c}\text { Программное } \\
\text { обеспечение и IT } \\
\text { сервисы }\end{array}$ & NYSE & 16.09 .20 & 3,864 \\
\hline 5 & Airbnb & CША & Потребительский & $N A S D A Q$ & 10.12 .20 & 3,83 \\
\hline
\end{tabular}

IPO заинтересовались компании из разных секторов экономики, однако было заметно преобладание ряда из них. Активнее всего в 2020 году были инвестиционные трасты и специализированные компании по целевым слияниям и поглощениям. Такие компании смогли привлечь $28 \%$ мирового объема средств (90,6 млрд. долл. США). $12,15 \%$ (39,4 млрд. долл. США) общемировых доходов привлекли производители программного обеспечения и IT сервисов. Растущая потребность в технологиях из-за перехода привычной жизни в онлайн-формат создала идеальные условия для технологических компаний. Третье место заняли фармацевтические компании, собрав 30,8 млрд. долл. США [1].

Никто не мог предположить, что период, сопровождаемый глобальными экономическими проблемами, вызванными пандемией, повышенным уровнем безработицы и высокой волатильностью рынка, станет годом рекордных IPO.

Пандемия вместе с цифровизацией облегчила проведение до этого многодневного роуд-шоу путем перевода их в дистанционный формат. Такой шаг позволил расширить круг потенциальных инвесторов и ускорил процесс подготовки к размещению.

На основе вышеизложенного можно выделить ряд положительных влияния пандемии на рынок IPO.

1. Активный рост IPO на фоне общего роста рынка ценных бумаг и заинтересованности инвесторов в новых объектах вложений - в период пандемии инвестициями заинтересовалось больше людей из-за вынужденной самоизоляции.

2. Развитие форматов процедур, лежащих в основе IPO, как, например, интерактивная подача документов регуляторам, проведение роуд-шоу в онлайн-режиме и иные инструменты цифровизации, появившиеся и получившие распространение благодаря пандемии.

3. Стимулирование интереса IT-компаний как наиболее конкурентоспособных в современной экономической среде к IPO - их финансовые возможности за время пандемии существенно возросли, и IPO стало следующим направлением для привлечения инвестиций после многочисленных раундов private equity.

Вместе с тем, можно выделить и аспекты негативного влияния, а именно. 
1. Увеличение сроков реализации уже намеченных проектов IPO, необходимость их переноса из-за приостановки деятельности многих учреждений и партнеров.

2. Повышение волатильности на рынке ценных бумаг, в условиях которой привлекательность новых ценных бумаг, и без того подверженных чрезмерным отклонениям в цене, стала ниже из-за возросшей рискованности вложений.

3. Неопределенность, охватывающая все сферы экономики, включая финансовый сектор и рынок ценных бумаг - в условиях неопределенности крупные проекты по привлечению инвестиций принимают на себя большее количество рисков.

$$
* * *
$$

1. Refinitiv URL: https://www.refinitiv.ru/ru (дата обращения: 17.11.2021).

2. Affirm Postpones Its Initial Public Offering // The Wall Street Journal URL: https://www.wsj.com/articles/affirmpostpones-initial-public-offering-sources-say-11607801619 (дата обращения: 17.11.2021).

3. Хритинина Д.В. Влияние пандемии коронавирусной инфекции на рынок IPO // Международный журнал гуманитарных и естественных наук. 2021. № 5-2 (56). С. 298-301.

\section{Лайпанов А.А., Гебенов Р.М. \\ Особенности бухгалтерского учёта в разных странах}

Северо-Кавказская государственная академия

(Россия, Черкесск)

doi: 10.18411/trnio-12-2021-40

\section{Аннотация}

Статья описывает особенности ведения бухгалтерского учёта и форм бухгалтерской отчётности в разных странах. В ней представлены источники конкретных форм бухгалтерского учёта и отчётности, а также их пользователи.

Ключевые слова: бухгалтерский учёт, бухгалтерская отчётность, особенности.

\section{Abstract}

The article describes the features of accounting and accounting reporting forms in different countries. It presents the sources of specific forms of accounting and reporting, as well as their users.

Keywords: accounting, accounting reporting, features.

Бухгалтерский учёт - система методов сбора, записи, хранения, преобразования и предоставления экономической информации. Целью бухгалтерского учёта является предоставления достоверной экономической информации обо всех операциях, происходящих на предприятии. Позднее эта информация будет использована для принятия соответствующих экономических решений. Руководитель предприятия или его собственники принимают решение о формировании дальнейшей политики предприятия, акционеры и акционерные общества производят оценку экономического потенциала предприятия, государство производит контроль предприятия на основании результатов бухгалтерского учёта.

Использование бухгалтерского учёта на всех предприятиях во всех странах мира является закономерным и неотвратимым явлением. Однако, даже несмотря на это, в разных странах политика в отношении структуры бухгалтерского учёта, порядка его оформления и наполнения, могут кардинально отличаться. Некоторые страны не имеют правовых норм, устанавливающих порядок ведения бухгалтерского учёта и оформления бухгалтерской отчётности, ограничиваясь лишь требованиями к перечню информации, предоставляемой 